\title{
Domestic Resource Mobilisation for Development in Pakistan
}

\author{
SARFRAZ K. QuRESHI, Musleh-Ud Din, EJAZ GHANI, and KalBe ABbaS
}

\begin{abstract}
This paper examines the determinants of private, domestic, and household savings in Pakistan. The analysis shows that private savings can be expected to grow gradually as a result of rising per capita income, falling dependency burden, improved financial deepening, and macro stability. Bivariate causality tests between GNP and savings show that GNP causes both domestic and public savings. However, the causality test is inconclusive in the case of causation between GNP and private savings. This finding has important policy implication in the sense that once a virtual cycle succeeds in accelerating growth, saving would catch up with a lag. In this sense, financing of investment is not a major constraint. The paper underlines the following policy options: (i) a strong effort spread over tax policy (tax reforms as well as tax administration), expenditure restraint, effective expenditure management, and public sector corporate reforms should aim at raising public savings to about 6 percent of the GDP; (ii) the incentives for private savings in Pakistan need to be revamped.
\end{abstract}

\section{INTRODUCTION}

The task of poverty alleviation and catching up with the fast-growing Asian countries requires Pakistan to target and achieve at least a 7 percent annual growth over the next 15 years. The key question in this context is whether Pakistan can position itself in a policy and institutional sense to finance the needed investment through increased domestic savings without undue recourse to foreign savings which introduces an element of unsustainability. The analysis of Pakistan's savings potential and how best it may be drawn on is a central issue at this time, since any optimistic scenario of future growth depends on a considerable increase in the national savings rate from its current low level. The average saving rate over 1990-91 to 1995-96 has been only 14.7 percent of GDP. It is essential to get this rate up to 20 percent and desirable to get it to 25 percent as soon as possible. How may this be achieved is an issue that we address in this paper.

A strategy to improve Pakistan's saving rate needs to benefit from the recent insights in the saving, investment and growth literature. Tax and interest rate instruments are important policy tools but need to be a part of an overall policy package aimed at

Sarfraz K. Qureshi is Director of the Pakitan Institute of Development Economics, Islamabad. Musleh-ud Din and Ejaz Ghani are Senior Research Economists and Kalbe Abbas is Research Economist at the Pakistan Institute of Development Economics.

Authors' Note: The version presented here has been revised from an earlier draft. 
fostering growth through improved productivity and financial liberalisation. The financial instruments requiring particular attention are a well functioning stock market, fully-paid compulsory pension and provident fund schemes with wide coverage and postal and national savings schemes which lower the transaction cost for savers emerging largely from geographical spread of post offices in rural areas whose savings need to be mobilised.

Section 2 provides a discussion of the methodology of savings estimation and points out the weaknesses in savings data in Pakistan. The measurement problem should be kept in view while reviewing trends in Pakistan's savings rates as well as Pakistan's savings performance relative to other countries. Section 3 presents information on trends in savings, structure of savings and the saving performance of Pakistan relative to other countries. Section 4 presents an analysis of the determinants of savings. Section 5 outlines elements of a strategy for obtaining higher savings in Pakistan. The final section summarises main conclusions.

\section{METHODOLOGY OF SAVING ESTIMATION AND MEASUREMENT BIASES IN OFFICIAL DATA ON SAVINGS IN PAKISTAN}

In the existing official methodology of national income accounting in Pakistan, national saving is estimated indirectly as a residual. The residual is computed at two stages. At the first stage, the difference between aggregate imports of goods and services $(M)$ and aggregate exports of goods and services $(X)$ yields estimates of foreign saving $(F)$. At the second stage, national saving $(S)$ is estimated as the difference between total investment $(I)$ and foreign saving.

National saving consists of public and private savings. Private saving $\left(S_{p}\right)$ is estimated as the difference between national saving and public saving $\left(S_{g}\right)$. Public saving is derived from budgetary accounts, which contain elements both from revenue and capital accounts of the budget and self-financing by public corporations, local bodies, and banking/insurance companies.

Corporate saving $\left(S_{c}\right)$ is derived simply by a factor income payments approach based on balance sheets of joint stock companies, i.e., the sum of depreciation and retained earnings. The difference between private saving and corporate saving yields household sector saving $\left(S_{h}\right)$ in Pakistan.

The above estimation of various forms of savings indicates that the estimates of national saving, in general, and household saving in particular, are susceptible to all the errors that occur in the figures of total investment and foreign savings, i.e., an underestimation of investment results in an underestimation of saving.

In Pakistan, at present there are two official series of data on savings. National savings estimates prepared by Planning Commission (used also in the State Bank of Pakistan, Annual Report) and those by the Federal Bureau of Statistics (FBS) differ 
mainly because of the different sources of foreign trade data used in the estimation of foreign savings. The trade figures used by Planning Commission are derived directly from the balance of payments data compiled by the State Bank of Pakistan (SBP), while the FBS series are based on their own compilation of foreign trade figures on customs data on physical movement of goods and services. Both measures are legitimate in the sense that payments data by the SBP capture the movement of funds which finance trade, while customs data by the FBS reflect more accurately the actual movement of goods and services in international trade. In principle, national accounts estimates should measure physical movements of goods and services, and therefore, national saving should be based on FBS data. But the main limitation of the FBS data is that it does not include public sector imports in its import figures. We use saving data compiled by the State Bank of Pakistan as the coverage of imports from this source is wider than that of Federal Bureau of Statistics saving series. The magnitude of domestic savings, being a residual, is subject to the accuracy of the gross investment figures and the balance of payments statistics. The exclusion of smuggling from balance of payments statistics introduces an element of error. The less than satisfactory coverage of investment in the informal sector adds another element of error in the investment figures. Whether unrecorded investment in the informal sector equals the unrecorded savings in this sector is an open question on which no hard evidence is available. A recent study on savings in Pakistan [Hook (1997)] maintained that savings in the informal sector have been under-estimated by about 4 percent of gross domestic product.

\section{COMPOSITION AND TRENDS IN SAVINGS RATES}

Pakistan's saving performance is evaluated in two ways. We provide information on relative saving and investment rates in Pakistan and a few other selected Asian countries. We trace the trends in different measures of savings over time. The sources of savings and how these have changed over time is also an important issue.

Table 1 presenting investment and saving as percent of GNP for the period 1976 to 1995 shows that Pakistan in both savings and investment is not well placed relative to most countries. Pakistan has been investing a significantly lower percent of GNP than all countries except Bangladesh. On the savings side, gross domestic saving rate of Pakistan at 11 percent of GNP is lower than all other countries except Bangladesh.

Pakistan has not only under-saved and under-invested relative to successful countries in the region who had experienced sustained high growth, its saving performance has also not improved much over time. Table 2 presents data on saving rates on an annual basis for the period 1960-61 to $1995-96 .{ }^{1}$

${ }^{1}$ Data on savings rates from 1947-48 to 1959-60 separately for West Pakistan (present Pakistan) are sketchy. A recent careful analysis of savings rates shows it to be rising from 2.0 percent in 1949-50 to 6.5 percent in 1959-60 [Pervez Hasan (1997)]. 
Table 1

Investment and Savings Rates: 1976-1995

\begin{tabular}{lcccccc}
\hline & $\begin{array}{c}\text { Gross } \\
\text { Country }\end{array}$ & $\begin{array}{c}\text { Gross National } \\
\text { Investment }\end{array}$ & $\begin{array}{c}\text { Gross } \\
\text { Somestic } \\
\text { Saving }\end{array}$ & $\begin{array}{c}\text { Net Factor } \\
\text { Income }\end{array}$ & $\begin{array}{c}\text { Foreign } \\
\text { Saving }\end{array}$ & $\begin{array}{c}\text { Gap: Dom: } \\
\text { Saving Gross } \\
\text { Investment }\end{array}$ \\
\hline Bangladesh & 12.6 & 5.6 & 3.0 & 2.6 & 7.0 & -9.6 \\
China & 36.5 & 37.0 & 36.9 & 0.1 & -0.5 & 0.5 \\
India & 22.9 & 22.0 & 22.7 & -0.8 & 1.1 & -0.2 \\
Indonesia & 29.5 & 27.4 & 31.7 & -4.3 & N.A. & 2.2 \\
Korea & 32.9 & 30.3 & 32.4 & -2.0 & 2.3 & -0.6 \\
Malaysia & 32.7 & 30.1 & 35.6 & 5.5 & N.A. & 2.9 \\
Pakistan & 17.9 & 15.9 & 11.0 & 4.9 & 2.1 & -6.9 \\
Philippines & 24.6 & 21.5 & 21.7 & -0.3 & 3.4 & -2.8 \\
Sri Lanka & 24.9 & 12.3 & 14.1 & -1.8 & 12.6 & -10.8 \\
Taipei, China & 24.9 & 31.8 & 30.7 & 1.0 & -6.8 & 5.8 \\
Thailand & 32.9 & 27.6 & 29.0 & -1.4 & N.A. & -3.9 \\
\hline
\end{tabular}

Source: Andrew T. Hook (1997) Savings in Pakistan: Practice and Policy. State Bank of Pakistan, Karachi. Note: N.A. denotes 'not available'.

For the period 1960-61 to 1995-96, domestic saving rates of 9.66 percent is low. A much more disturbing feature of the savings performance is that the saving rate has fallen over time from 13.54 percent during 1960s to 8.44 percent during 1970 s. The savings improved slightly during 1980s and 1990s and was slightly higher than 1960s. There have also been large fluctuations in the saving rates. Another disturbing feature is that national saving has been able to finance, on average, 3/4th of gross total investment in Pakistan during the last 25 years. In other words, 1/4th of total investment has been financed by foreign resources. Considering the fact that the era of concessionary loan flows is over, if this trend is allowed to continue, it will raise the already high outstanding debt and debt servicing liability.

Private saving consists of household and corporate savings. Private saving as percentage of GDP (private savings rate) has also remained low and stagnant at around 12 percent during the last 25 years. Household saving as percentage of GDP (household saving rate) reported in Table 2 presents a dismal picture. It remained abysmally low and stagnant around less than 11 percent during the last 25 years. The performance of the corporate sector saving has been very poor. It has averaged at 1.31 percent of GDP during the last 25 years. Interestingly, it has registered some improvement in the 1990s as compared with the earlier years.

Public savings as percentage of GDP (public savings rate) presents a dismal picture as it averaged 1.99 percent and 2.31 percent respectively during the 1960-1996 and 19911996 period. One of the prime reasons for the low and stagnant domestic saving rate in Pakistan has been the abysmally poor performance of public saving rate. Unless serious efforts are made to raise public saving rate in the neighbourhood of 6 to 7 percent and 
Table 2

Trends in Savings in Pakistan

\begin{tabular}{|c|c|c|c|c|c|}
\hline Years & Public Savings & $\begin{array}{c}\text { Private } \\
\text { Savings }\end{array}$ & $\begin{array}{l}\text { Household } \\
\text { Savings }\end{array}$ & $\begin{array}{c}\text { Corporate } \\
\text { Savings }\end{array}$ & $\begin{array}{c}\text { Domestic } \\
\text { Savings }\end{array}$ \\
\hline $1960-61$ & 2.11 & 7.01 & 3.91 & 0.95 & 9.25 \\
\hline $1961-62$ & 2.20 & 5.84 & 4.42 & 0.97 & 8.27 \\
\hline $1962-63$ & 1.81 & 10.90 & 8.19 & 1.21 & 12.93 \\
\hline $1963-64$ & 2.23 & 14.62 & 9.63 & 1.49 & 16.99 \\
\hline $1964-65$ & 2.28 & 16.69 & 6.71 & 1.37 & 19.16 \\
\hline $1965-66$ & 2.37 & 10.61 & 13.75 & 1.39 & 13.14 \\
\hline $1966-67$ & 2.58 & 13.66 & 9.27 & 1.38 & 16.38 \\
\hline $1967-68$ & 2.92 & 9.48 & 11.09 & 1.59 & 12.45 \\
\hline $1968-69$ & 3.15 & 8.79 & 8.49 & 1.62 & 12.01 \\
\hline $1969-70$ & 0.95 & 8.02 & 0.65 & 1.54 & 13.06 \\
\hline $1960-61$ to $1969-70$ & 2.26 & 10.53 & 7.57 & 1.41 & 13.54 \\
\hline $1970-71$ & 0.74 & 7.74 & 6.47 & 1.26 & 12.95 \\
\hline $1971-72$ & -0.33 & 9.67 & 8.48 & 1.19 & 12.32 \\
\hline $1972-73$ & -0.47 & 11.18 & 9.60 & 1.58 & 10.00 \\
\hline $1973-74$ & -0.15 & 7.16 & 5.85 & 1.31 & 6.31 \\
\hline $1974-75$ & 0.60 & 6.56 & 5.08 & 1.48 & 4.95 \\
\hline $1975-76$ & 0.81 & 10.45 & 9.21 & 1.24 & 8.96 \\
\hline $1976-77$ & 2.45 & 9.87 & 0.87 & 1.17 & 8.66 \\
\hline $1977-78$ & 1.81 & 12.67 & 11.49 & 1.18 & 7.59 \\
\hline $1978-79$ & 1.06 & 11.17 & 10.02 & 1.15 & 5.81 \\
\hline $1979-80$ & 2.20 & 11.49 & 10.01 & 1.48 & 6.87 \\
\hline $1970-71$ to $1979-80$ & 0.87 & 9.80 & 7.71 & 1.30 & 8.44 \\
\hline $1980-81$ & 4.17 & 9.25 & 7.78 & 1.46 & 6.34 \\
\hline $1981-82$ & 3.35 & 9.18 & 7.58 & 1.60 & 8.13 \\
\hline $1982-83$ & 1.27 & 14.72 & 13.05 & 1.67 & 8.38 \\
\hline $1983-84$ & 2.02 & 11.70 & 10.06 & 1.64 & 7.65 \\
\hline $1984-85$ & 0.38 & 12.55 & 12.15 & 0.40 & 6.71 \\
\hline $1985-86$ & 1.71 & 13.18 & 12.62 & 0.56 & 8.78 \\
\hline $1986-87$ & 0.49 & 16.48 & 15.44 & 1.05 & 12.28 \\
\hline $1987-88$ & 1.33 & 12.30 & 11.35 & 0.95 & 10.56 \\
\hline 1988-89 & 0.19 & 13.89 & 13.03 & 0.86 & 10.44 \\
\hline $1989-90$ & 2.84 & 11.35 & 10.15 & 1.20 & 11.75 \\
\hline $1980-81$ to $1989-90$ & 1.60 & 12.71 & 11.64 & 1.07 & 9.65 \\
\hline $1990-91$ & 0.70 & 13.48 & 12.03 & 1.46 & 12.67 \\
\hline $1991-92$ & 4.27 & 12.80 & 11.39 & 1.41 & 16.66 \\
\hline $1992-93$ & 1.50 & 12.06 & 10.68 & 1.39 & 13.44 \\
\hline $1993-94$ & 2.56 & 13.09 & 11.55 & 1.54 & 15.95 \\
\hline $1994-95$ & 2.05 & 12.70 & 11.20 & 1.50 & 14.52 \\
\hline $1995-96$ & 2.49 & 11.24 & 9.91 & 1.33 & 14.46 \\
\hline $1990-91$ to $1995-96$ & 2.31 & 12.43 & 10.99 & 1.43 & 14.67 \\
\hline $1960-61$ to $1995-96$ & 1.99 & 12.39 & 10.98 & 1.31 & 9.66 \\
\hline
\end{tabular}

Source: State Bank of Pakistan, Annual Report (Various Issues), Karachi. 
private saving rate in the neighbourhood of 16 to 17 percent of GNP, Pakistan's desire to raise saving rate closer to the average of developing countries (23 percent) will remain a distant dream. For Pakistan to join the rank of the "Asian Tiger", a saving rate of more than 35 percent is needed. Given the current low rate of saving it is highly improbable that Pakistan will come even closer to attain the rank of the "Asian Tiger" in the distant future unless serious efforts are made to raise both public and private saving rates.

Table 3 presents data on revenue and expenditure. A quick look reveals the factors behind the low and deteriorating public savings in Pakistan. While the development expenditure as a percent of GNP has been restrained, the current expenditure has increased sharply. There has been no significant increase in the proportion of tax and non-tax revenue in GNP. The failure to institute a serious tax reform programme and to exercise fiscal restraint in Pakistan have jointly been responsible for the dismal performance of public savings.

Table 4 summarises net financial balances of the private sector, the public sector, and the overall economy in Pakistan. It shows that public savings followed an upward trend during 1970-96. They reveal that annual average public savings were 0.8 percent of GDP in 1970s, which increased to 1.8 percent in 1980s and 2.3 percent of GDP in 1990s. Conversely, public investment had declined from annual average 9.3 percent of GDP in 1970s to 9.2 percent in 1980s and 8.5 percent of GDP in 1990s. An upward trend in public savings and a downward trend in public investment had limited the worsening in the government net financial balance during the period 1970-96. Table 4 also shows that annual average net balance of the public sector improved from 8.5 percent of GDP in 1970s to 7.4 percent in 1980s and 6.2 percent of GDP in 1990s. It should be noted, however, that public sector had always been getting an inflow of funds from the private sector.

In Pakistan, private savings have been substantially higher than public savings throughout the period under consideration. They increased from an average of 9.6 percent of GDP in 1970s to almost 12.5 percent of GDP in 1980s and 1990s. On the other hand, private investment expanded from the average of 7.0 percent of GDP in 1970s to 9.6 percent in 1980s and 10.9 of GDP in 1990s. Consequently, the net financial balance of the private sector deteriorated from 2.6 percent of GDP in 1970s to 2.9 percent of GDP in 1980s. It improved somewhat in 1990s. The surpluses of the private sector were transferred to the public sector to meet its budgetary requirements.

Table 4 also shows the evolution of overall net balance of Pakistan's economy, which is identical to the current account deficit of the balance of payments. It shows that the overall net balance improved from an annual average of 5.9 percent of GDP in 1970s to almost 4.5 percent of GDP during 1980s and 1990s. 


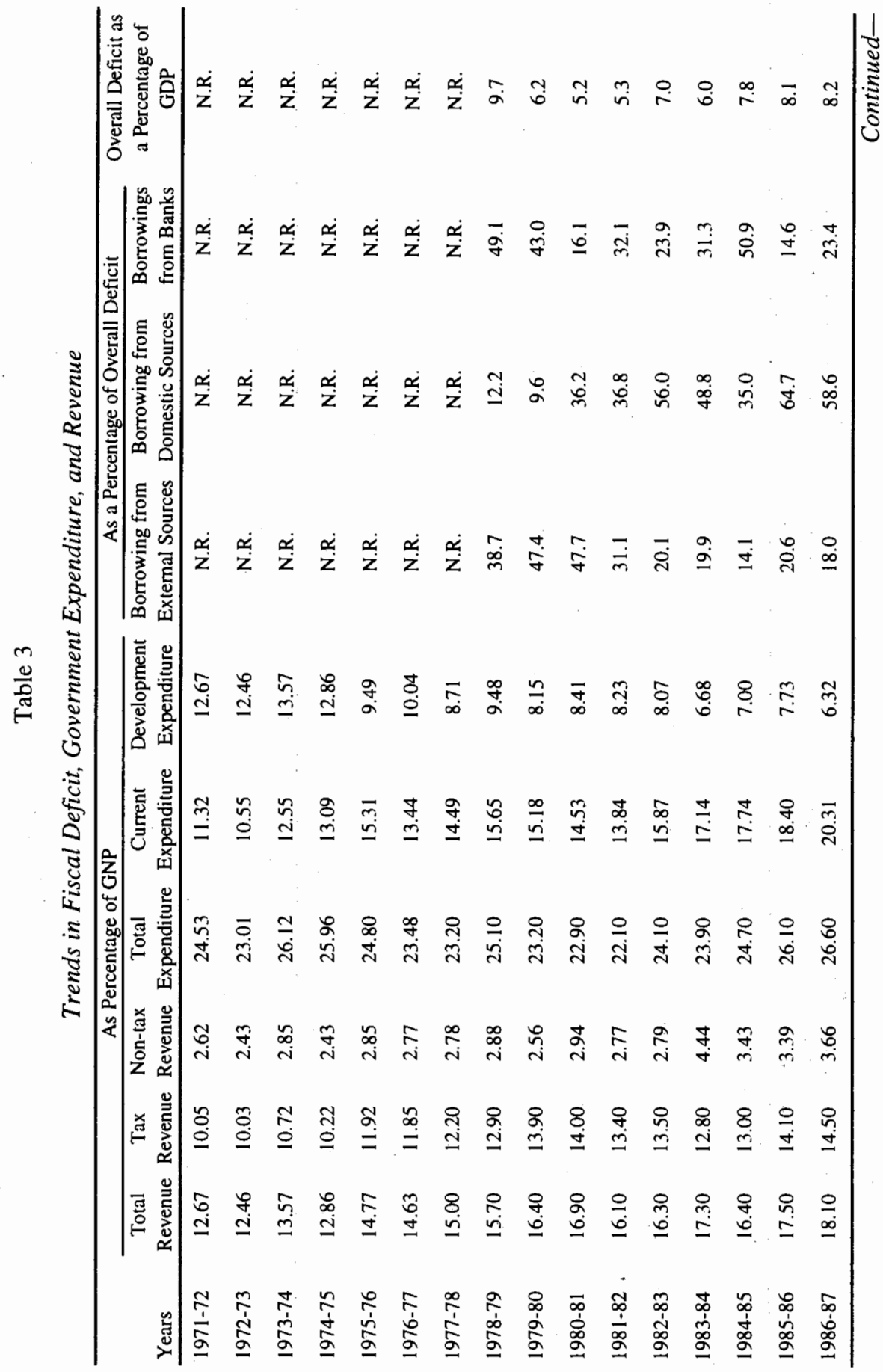




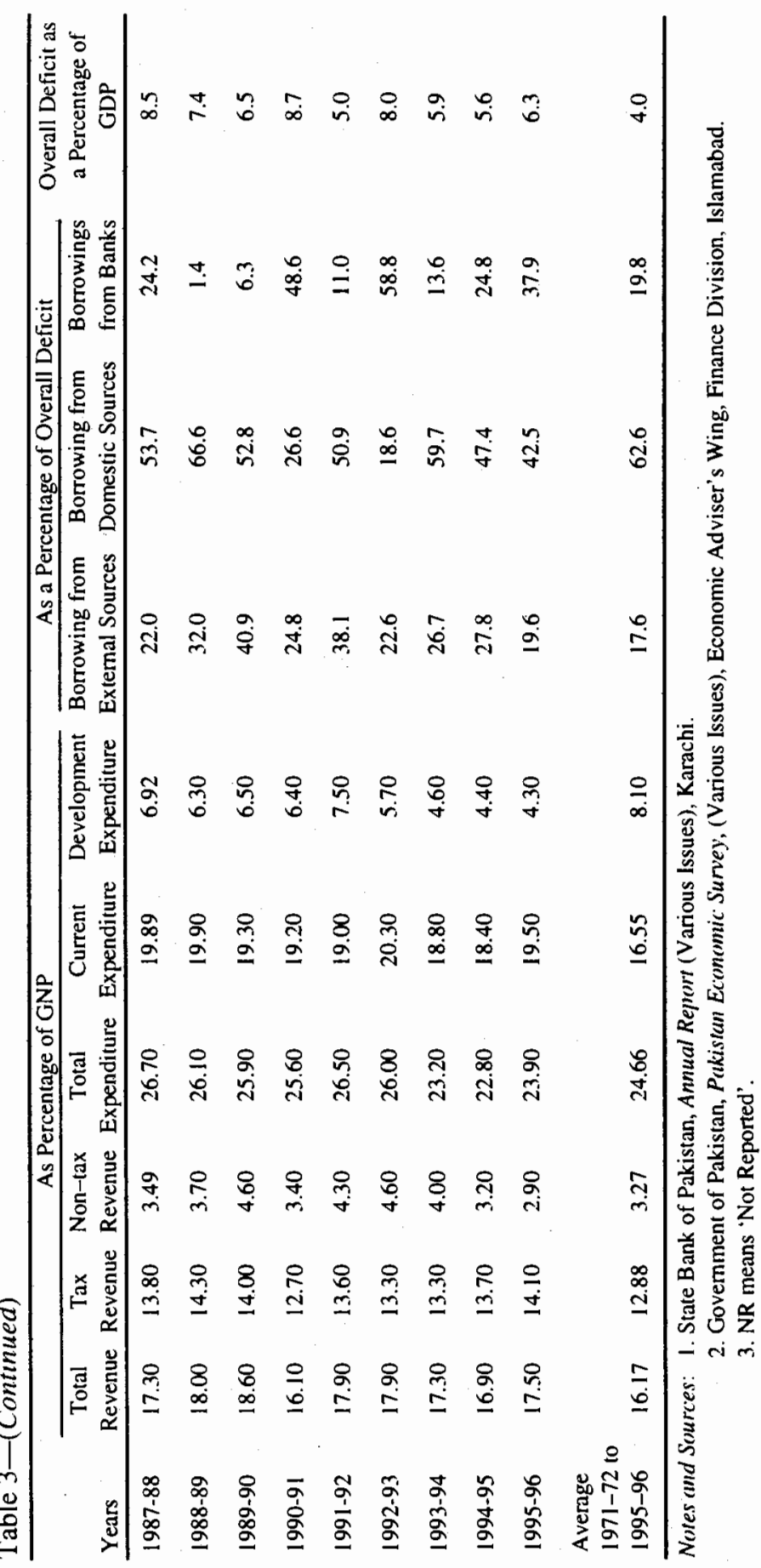




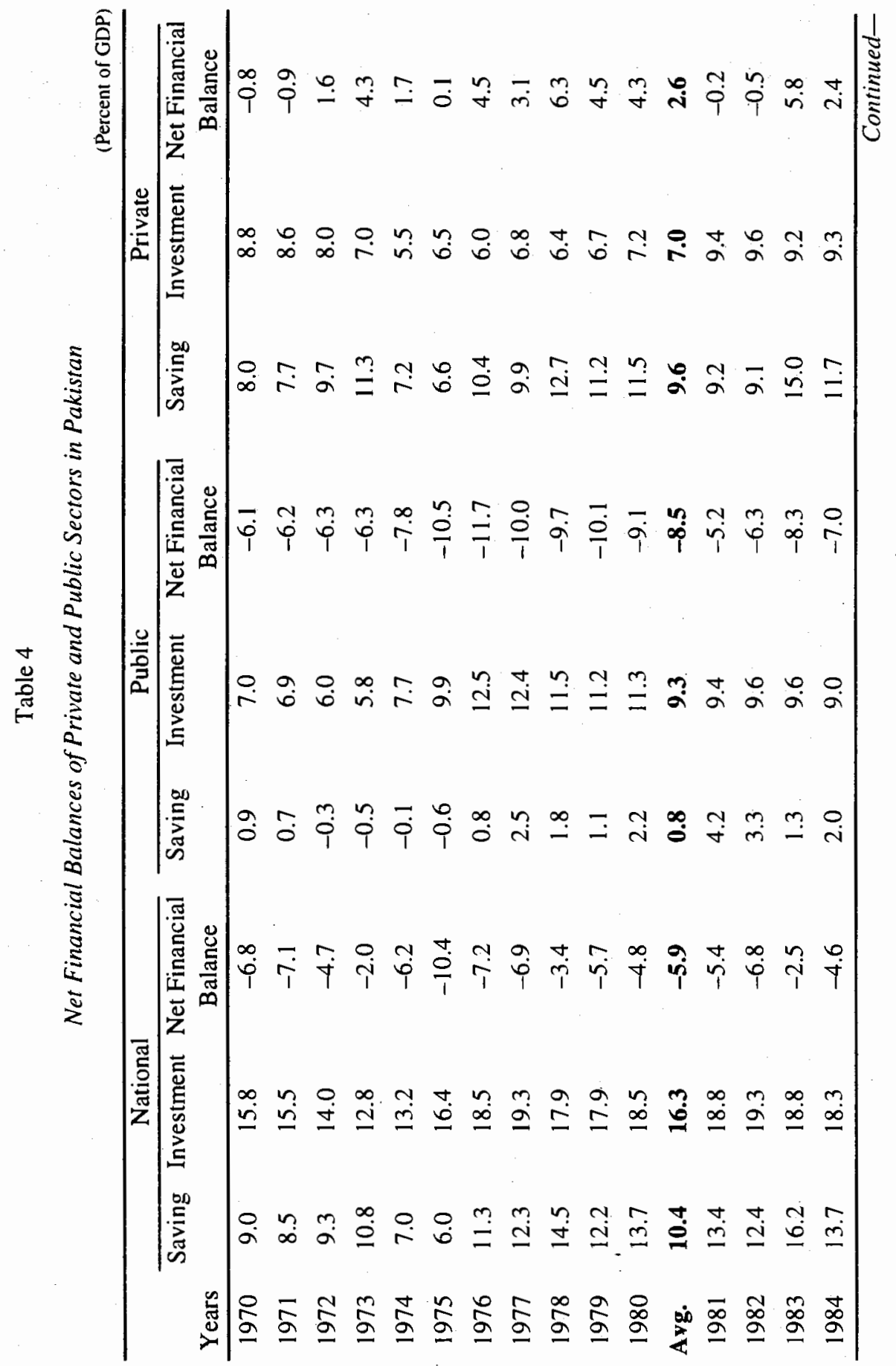




\section{DETERMINANTS OF SAVINGS IN PAKISTAN}

In second section, evidence on main determinants of savings in East Asia was presented. In this section, we first provide a review of empirical literature drawing largely on previous studies in the context of Pakistan. We find that results are broadly consistent with standard economic theory. However, the statistical significance of some of the variables has been found to be weak. Also the directions of relationship between growth and saving need to be examined. Due largely to this omission in previous literature, we provide further analysis on determinants of savings. We explicitly discuss the Ricardian Equivalence proposition in terms of the impact of changes in public savings on private savings and household savings. The specific issue addressed in this context is how much private savings would be displaced due to increase in public savings.

\subsection{Review of Literature}

This section presents a brief review of the empirical literature on the behaviour of savings in the context of Pakistan's economy. Qureshi (1981) investigated the relative explanatory power of permanent vs current income in explaining variation in the rate of household saving in Pakistan. The study showed that the permanent income model that emphasises short term adjustment lags between income and expenditure provided a much better explanation of the variation in household saving. The study also examined the effect of real interest rate on household saving and found a strong and positive relationship between these two variables. The study showed a negative impact of inflation on the rate of household saving in Pakistan.

Khan (1988) and Khan et al. (1994) analysed the behaviour of savings in the context of McKinnon-Shaw model of financial repression. According to the McKinnonShaw thesis, it is not the cost of capital but rather the availability of financial resources that constrain investment in financially repressed economies. Contrary to the conventional view, the McKinnon-Shaw model emphasises a positive relationship between investment and the real rate of interest. This is because an increase in the real rate of interest induces more savings which in turn raises the level of investment by relaxing the financial constraints. Both the studies found strong support for the McKinnon-Shaw hypothesis.

Khan et al. (1994) examined the determinants of national saving rate in Pakistan in terms of a variety of factors that include income, real interest rate, dependency ratio, foreign capital inflow, foreign aid, changes in the term of trade, and openness of the economy. The study found a strong and positive effect of per capita GNP on national savings. However, the study reported an insignificant impact of the growth rate of real income on national savings. The study showed that real interest rate, change in the term of trade, and openness of the economy positively influence national saving. Both debt to GNP ratio and dependence rate were found to have an adverse impact on national 
saving. The study showed that foreign capital inflow discouraged national saving in the current period. However foreign capital inflow was found to have a positive influence on national saving with lags of one and two periods.

Finally, Hussain (1996) explored the determinants of private saving in terms of demographics, growth, and financial deepening. The study estimated a long run equilibrium relationship for the period 1970-1993. This relationship indicated that the private saving rate cointegrates with the financial deepening variable and the time trend. Hence, long run movement in the rate of private saving in Pakistan may be explained by long run movements in financial deepening and the time trend. To the extent that the variables not included in the estimation, such as net wealth and net government debt, are correlated with the time trend, the results appear to suggest that these variables also influenced long run movements in the rate of private saving. Finally, the study found that demographics did not influence private saving rate in Pakistan.

\subsection{Determinants of Private, Domestic, and Household Savings}

This section provides an empirical assessment of the role of income, public saving, real interest rate, financial deepening, foreign capital inflows, and other demographic and structural factors in the determination of private, domestic, and household savings in Pakistan. Regression equations have been estimated by ordinary least squares (OLS) for private saving, domestic saving, and household saving for the period 1961-1996. The estimated equations are reported in Table 5 Equation 1 explains private saving in terms of public saving, GNP, Financial Deepening (measured as a ratio of M1 to GNP), ratio of value added in agriculture to GDP (VAGDP), foreign capital inflows, and real interest rate. In this equation, GNP, financial deepening, and real interest rate positively influence the dependent variable, while public saving, foreign capital inflows, and ratio of value added in agriculture to GDP have a negative impact on private saving. Equation 2 explains domestic saving in terms of GNP, financial deepening, ratio of value added in agriculture to GDP, foreign capital inflow and real interest rate. In this equation, GNP, financial deepening, and ratio of value added in agriculture to GDP positively influence the dependent variable. Both GNP and foreign capital inflow are statistically significant while ratio of value added in agriculture to GDP and financial deepening are statistically insignificant. Real interest rate has a negative but statistically insignificant co-efficient. Equation 3 explains household saving in terms of public saving, GNP, real interest rate, foreign capital inflows and dependency ratio. In this equation, both public saving and foreign capital inflows negatively influence the dependent variable while GNP, real interest rate and dependency ratio have a positive impact on household saving. All the variables except dependency ratio are statistically significant in this equation.

Public saving is included as an explanatory variable in the equations for private and household savings to test Ricardian Equivalence. The co-efficient of public saving 


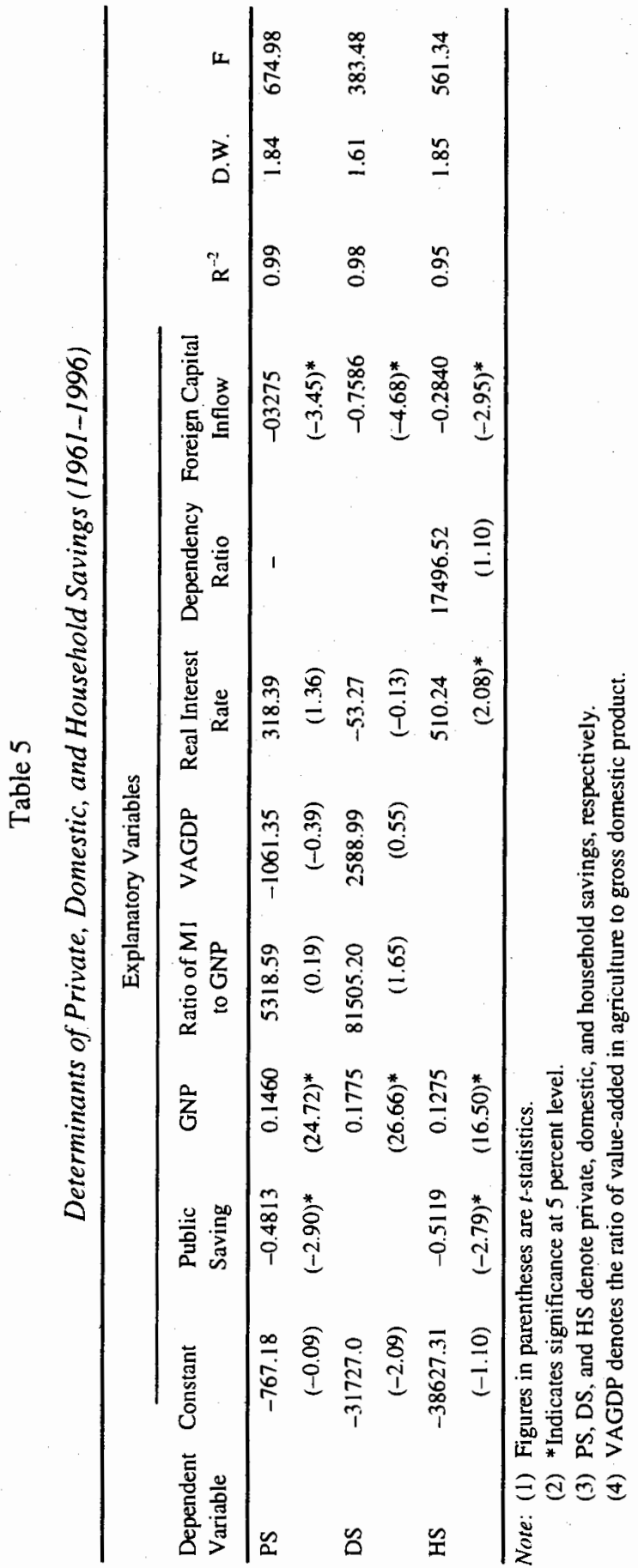


has a negative sign in the equations for private and household savings, confirming that public savings do crowd out private and household savings. However, the low magnitude of this co-efficient indicates that public savings have not fully crowded out private savings. ${ }^{2}$ For example in equation 1 of Table 5 an increase of one rupee in public savings leads to a reduction of 48 paisa in private savings. Thus the Recardian Equivalence proposition does not appear to hold fully in the context of Pakistan's economy.

We have also tested for the direction of causation between GNP and private saving, domestic saving, and public saving in turn. Appendix I reports the results of Engle-Granger Causality tests. The results show that GNP causes both domestic and public savings. However, the causality test is inconclusive in the case of causation between GNP and private saving. This finding has important policy implication in the sense that once a virtuous cycle succeeds in accelerating growth, savings would catch up with a lag. In this sense, financing of investment is not a major constraint. It would get relaxed with time as has been the case of many East Asian countries.

\section{STRATEGY AND POLICY OPTIONS FOR INCREASING SAVINGS}

There are two issues that need to be addressed at the very outset. First, the target level of domestic savings required to finance the investment needs for achieving the objective of 7 to 8 percent growth in the economy needs to be known. This exercise requires, among other things, the expected sectoral composition as different sectors vary in their capital requirements and expected changes in the efficiency of investment would in future years. In view of the current infrastructural constraints, it is expected that future investment would be characterised with a high level of Incremental Capital Output Ratio (ICOR) as investments in the infrastructural sectors has a higher ICOR than most other sectors. If the improvements in the efficiency of investments does not fully offset the impact of larger required investments in infrastructures, it is expected that ICOR would increase over time in Pakistan.

Table 6 presents ICOR measures for Pakistan, India and a few other countries. The countries in South-East Asia had a strong economic reforms programme which had a favourable impact on the efficient use of resources. Despite increased efficiency of investment, the ICOR have been in excess of 4 . It, therefore, appears that given the high infrastructural needs of the Pakistani economy, it is quite probable that Pakistan's ICOR would rise to about 4.5 over the next 10 years or so. Given the target growth rate of 7 percent, it implies that investment rate needs to increase to over 30 percent. Assuming some recourse to foreign savings, the domestic savings rates would need to rise to about 28 percent in the medium to long-term from the current rate of 14.46 percent in 1995-96.

${ }^{2}$ Notice that the negative coefficient may be upward biased due to errors of observation in the savings data. 
Table 6

Increased Capital Output Ratio (ICOR) Measures for Pakistan, India and East Asian Countries

\begin{tabular}{lccccc}
\hline & \multicolumn{1}{c}{} & & (Average Values) \\
\hline Pakistan & $1975-80$ & $1981-85$ & $1986-90$ & $1991-95$ & $1975-95$ \\
China & 3.16 & 2.78 & 3.31 & 5.11 & 3.59 \\
Indonesia & 0.82 & 3.54 & 5.02 & 3.48 & 3.44 \\
Malaysia & 3.07 & 5.59 & 5.27 & 4.98 & 4.73 \\
Thailand & 3.20 & 4.29 & 7.21 & 4.34 & 4.76 \\
India & 3.59 & 4.76 & 3.29 & 4.88 & 4.13 \\
\hline
\end{tabular}

Whether such an increase in domestic savings rates is feasible and, if so, what policy steps need to be taken is the issue we turn to. We had shown that in East-Asia, some countries that had low saving rates initially were successful in raising savings to the required high levels. This was achieved by a mix of policies aimed directly at mobilising savings and by the initiation of a virtuous growth-saving circle by first putting in place a strong structural reforms programme that had increased efficiency of resource use and had resulted in sustained high growth. The accelerated growth had Granger-caused increased savings with a lag.

What events and/or policies might contribute to an increase in the savings rate? Among the possible candidates are:

(i) An increase in per capita income over time. Though Khan et al. (1994) report a strong and positive effect, it is noteworthy that although per capita incomes has risen by about 150 percent since the beginning of the 1960s the average savings ratio has shown no clear upward trend, raising the possibility that though short term increases in income coincide with increases in savings, this relationship is less in evidence, if at all, in the longer run.

(ii) An increase in the growth rate of per capita income. This variable, which seems to have played a role in some developing countries, did not have explanatory power in the cited Khan et al. study.

(iii) The real interest rate is other possible influence. The magnitude of its possible effect needs attention.

(iv) Trade and openness were reported by Khan et al. to have positive effects. This may be a good omen for Pakistan as it moves towards a more open economy. Foreign capital inflow has a reported negative effect in the current period though a positive one with lags of one and two years.

(v) Household savings have been positively related to the dependency ratio. An increasing dependency ratio indicates a higher burden on the working 
generation, increasing the need for retirement saving.

(vi) The level of financial deepening in the economy has a positive impact on savings. Thus savings rate is likely to improve as the economy achieves a greater level of financial deepening.

(vii) As for the structural effects, share of agriculture in GDP may be related to savings, as confirmed in this study but without statistical significance. The impact of this variable thus remains to be seen as well.

Most of the factors indicated above would raise the domestic savings rates gradually over time. The gradual projected increase in the saving rate would not suffice to finance the investment needs. A strong action on both the public and private saving front is, therefore, needed.

\section{Policy Options}

1. Public savings in Pakistan have been low and have declined over time. A strong effort spread over tax policy (tax reforms as well as tax administration), expenditure restraint, effective expenditure management and public sector corporation reforms should aim at raising public savings to about 6 percent of GDP. Higher public savings would depress, by a third, private savings through a Ricardian equivalence effect. On balance, an increase of domestic savings by 4 percent of GDP should be a significant step. The materialisation of increased public savings requires a strong public policy response. The only silver lining is that some countries had succeeded in this area.

2. The incentives for private savings in Pakistan need to be revamped. The paucity of long-term saving instruments, such as provident funds, life insurance and mutual funds has hindered the channelling of savings in productive uses. Markets in long-term saving instrument have been dominated by the public sector. The allocation of portfolios is heavily regulated which has resulted in the use of funds in areas of low returns. There is a need to introduce flexibility to enable actors to respond to market developments and not be bound by government dictate.

3. The provident fund system in Pakistan provides defined-contribution retirement schemes for not more than 6 percent of the labour force. Public sector employees receive an additional budget-financed government pension.

In addition to policies aimed at increasing the rate of voluntary saving, the Government needs to adopt measures to generate involuntary saving through mandatory pension schemes. There are two types of such schemes: unfunded social security or pay as you go (PAYG) schemes; and fully funded pension plans. While the social security 
systems of Europe and the United States are characterised by PAYG scheme, Japan, Malaysia, and Singapore have introduced fully funded mandatory pension plans. The impact of compulsory pension plans on aggregate saving depends on the extent to which they substitute for voluntary saving. Empirical evidence on the impact of pension funds on aggregate saving is generally mixed. For example, results for the United States show that unfunded social security had increased long-term saving and investment by only modest amounts. Empirical evidence for other industrial countries shows little or no effects of unfunded social security on contemporaneous private saving levels. In contrast, econometric evidence on Singapore's fully funded central Provident Fund shows that it has stimulated aggregate saving. Similarly, empirical evidence for Chile suggests that the substitution of fully funded for PAYG plans has contributed to Chile's large increase in private saving. It should be noted that increase in private savings in Chile occurred after a long time lag. Pakistan should introduce mandatory pension schemes with a very broad employee coverage in the private sector. In Pakistan, there is a need to improve the credit market to enable contribution of the provident fund system to borrow as and when they need to remove their liquidity constraints. This should lead to lesser withdrawal of funds from the provident fund system by its contributors who forego high returns from accumulation from provident fund only to meet short-term needs.

\section{CONCLUDING REMARKS}

Domestic savings in Pakistan have been low and have risen quite slowly. Public savings have been the major problem area in the past. An econometric analysis of private savings determinants shows that we can expect private savings to grow gradually as a result of rising per capita income, falling dependency burden, improved financial deepening and macro stability. If public savings remain low, private savings would not suffice to finance the high growth target needed to eradicate poverty as well as improve the general living standard. Part of the problem of a low savings rate would be solved if a virtuous cycle is created whereby high GDP growth contributes to an acceleration in the growth rate of savings.

The most promising strategy for Pakistan to raise its domestic saving rate is to raise public saving through tax and expenditure reforms, introduction of extensive compulsory forced saving schemes and opening of the private sector to provide financial instruments for long-term savings.

The development of a market for the long-term saving instruments can serve two major objectives. First, the efficient use of invisible funds can be promoted if government does not use funds mobilised to finance its fiscal deficit and/or its unproductive portfolio of public sector projects. The recent improvement in this area should be taken to its logical conclusion wherein resources raised through provident fund, insurance and mutual funds are allowed to be allocated to their best uses. Second, 
the National Provident Fund (NPF) mechanism has the potential to increase national savings only when certain conditions are met. First, the mandated savings must be beyond the level individuals would have voluntarily chosen to save. Second, individuals should not be allowed to find ways to evade the discipline imposed by forced savings through such means as additional borrowings. In this context, it is important to improve the functioning of credit market. Third, the government must not offset this saving by running a larger deficit. Indeed, there is a danger that the availability of continuous flow of funds through the government-controlled NPF mechanism may soften government's budget constraint, and this in turn could result in the selection of projects which do not pass the test of social benefit-cost analysis.

It should not be assumed that the introduction of the NPF will automatically result in increased private savings, let alone, in increased aggregate domestic savings. This is especially the case when a transition is being made from the PAYG to the NPF system, as those with claims on the system before transition would need to be compensated. Paying compensation would have a negative impact on government saving.

\section{APPENDIX I}

\section{Savings and Growth: Causality Tests}

The Appendix I reports the results of bivariate causality tests between GNP and private saving, domestic saving, and public saving in turn. A variable $X t$ is said to cause a variable $Y t$ in the Granger sense if the forecast for $Y t$ improves when lagged $X t$ 's are included in the regression. We employ the Engle-Granger Error Correction approach to test for the existence of a causal relationship. Prior to estimating an Error Correction Model (ECM), tests for the existence of unit roots were conducted for the time series of GNP, private saving, domestic saving, and public saving. The following table reports the results from Augmented Dickey Fuller (ADF) $t$-test. It is clear from these tables that the hypothesis of a unit root without trend is accepted for all the variables. Next, we tested for cointegration between GNP and the three categories of savings in turn.

Results of Augmented Dickey Fuller t-Test

\begin{tabular}{lccc}
\hline \multirow{2}{*}{ Period } & Variable & $t$-Statistic & $t$-Statistic \\
1961-1996 & LPS & -0.8739 & (With Trend) \\
& LPBS & -1.8978 & -2.4576 \\
& LDS & 0.1275 & -2.3498 \\
& LGNP & -0.2862 & -1.5762 \\
&
\end{tabular}

Notes: (1) For $t$-statistic without trend, Mackinnon critical values are $-3.6353,-2.9499$ and 2.6133 respectively at 1 percent, 5 percent and 10 percent level of significance. The corresponding critical values for $t$-statistic with trend are $-4.2505,-3.5468$ and -3.2056 .

(2) LPS, LPBS, LDS, and LGNP respectively denote logarithms of private, public, and domestic savings and GNP. 
The following table reports the cointegrating equations.

Engle-Granger Co-integration Test

\begin{tabular}{lllcc}
\hline Period & Co-integration Equations & Dickey Fuller Test & CRDW \\
\hline \multirow{4}{*}{$1961-96$} & LDS & $=1.518+0.944$ LGNP & -2.66 & 2.01 \\
& LGNP & $=2.324+0.987$ DS & -2.73 & 2.02 \\
& LPS & $=-2.276+1.01$ LGNP & -4.68 & 2.04 \\
& LGNP & $=2.798+0.935$ LPS & -4.60 & 1.99 \\
& LPBS & $=-13.899+1.701$ LGNP & -2.63 & 2.16 \\
LGNP & $=10.766+0.193$ LPBS & 1.52 & 2.04 \\
\hline
\end{tabular}

Having analysed the time series properties of the relevant variables, the following equations have been estimated for the three categories of savings.

$$
\begin{aligned}
& (1-L) N S_{t}=\sum_{i=1}^{m} \alpha_{i}(1-L) N S_{t-i}+\sum_{j=1}^{n} \beta_{j}(1-L) G N P_{t-j}+\varepsilon\left(N S_{t-1}-\lambda G N P_{t-1}\right) \\
& (1-L) G N P_{t}=\sum_{i=1}^{m} \gamma_{i}(1-L) G N P_{t-i}+\sum_{j=1}^{n} \delta_{i}(1-L) N S_{t-j}+\Psi\left(G N P_{t-1}-\theta_{N S_{t-1}}\right)
\end{aligned}
$$

where $L$ is the lag operator.

The table given below provides a summary of the causality tests. The F-test shows that GNP causes both domestic and public savings. However, the result is inconclusive in the case of private savings.

\begin{tabular}{cc}
\multicolumn{2}{c}{ Direction of Causation Based on F-Test } \\
\hline Variable & $1961-96$ \\
\hline DS on GNP & $2.89^{*}$ \\
GNP on DS & 0.71 \\
PS on GNP & 0.43 \\
GNP on PS & 0.42 \\
PBS on GNP & $6.77^{*}$ \\
GNP on PBS & 1.10 \\
\hline
\end{tabular}

Chart of Direction of Causation between Savings and Income

\begin{tabular}{llll}
\hline Period & From & & To \\
\hline \multirow{3}{*}{$1961-96$} & GNP & $==>$ & DS \\
& GNP & $--/--$ & PS \\
& GNP & $==>$ & PBS \\
\hline
\end{tabular}




\section{REFERENCES}

Hook, Andrew T. (1997) Savings in Pakistan: Practice and Policy. Karachi: State Bank of Pakistan.

Hussain, Aasim M. (1996) Private Saving and its Determinants: The Case of Pakistan. The Pakistan Development Review 35:1 49-70.

Hussain, Fazal (1996) Stock Price Behaviour in an Emerging Market: A Case Study of Pakistan. Unpublished Ph.D. diss., The Catholic University, USA.

Khan, Ashfaque H. (1988) Financial Regression, Financial Development and Structure of Savings in Pakistan. The Pakistan Development Review 29:4 701-714.

Khan, Ashfaque H. (1997) A Test of Causal Relation between Government Spending and Government Revenue: A Case Study of Pakistan. Pakistan Institute of Development Economics, Islamabad. (Report.)

Khan, Ashfaque H., L. Hasan, A. Malik (1994) Determinants of National Saving Rate in Pakistan. Economica Internationale 47:4.

Muhleisen, Martin (1997) Improving India’s Saving Performance. Washington, D. C., (IMF Working Paper.)

Muhleisen, Martin (1997) Improving India’s Saving Performance. Washington, D. C., (IMF Working Paper.)

Qureshi, Zia M. (1981) Household Saving in Pakistan: Some Findings from Time Series Data. The Pakistan Development Review 20:4 375-397. 